\title{
Fen Bilgisi Öğretmen Adaylarının E-Portfolyo Kullanımına Yönelik Görüşlerinin İncelenmesi: Bir Eylem Araştırması ${ }^{1}$
}

\author{
Fatma Tuba ÜLKER ${ }^{1} \&$ Serkan ÜNLÜ² \& Ertuğrul USTA ${ }^{3}$ \\ ${ }^{1}$ Necmettin Erbakan Üniversitesi, Türkiye \\ ${ }^{2}$ Necmettin Erbakan Üniversitesi, Türkiye \\ ${ }^{3}$ Necmettin Erbakan Üniversitesi, Türkiye
}

\begin{abstract}
$\ddot{O} z e t$
Bu araştırma performans değerlendirme yöntemi olarak kullanılan, e-portfolyo sisteminin kullanılabilirliği (olumlu, olumsuz yönleri) ve uygulama süreci ile ilgili fen bilgisi öğretmen adaylarının görü̈slerini almak amacıyla gerçekleştirilmiş̧tir. Bu kapsamda fen bilgisi ögretmen adaylarının uygulama çalışması sonucunda edinmiş oldukları deneyimlerden faydalanılmış̧ır. Eylem araştırması yönteminin kullanıldı̆̆ $\breve{g}_{\text {araştırma }}$ 2019-2020 öğretim yllında bir devlet üniversitesinde yürütülmü̈şür. Çalışma grubu Eğitim Fakültesi Fen Bilgisi Öğretmenliği Anabilim Dalında öğrenim gören ve "Bilimin Teknolojideki Uygulamaları" seçmeli dersini alan 17 ögrenciden oluşturulmuştur. Araştırma verileri 10 hafta boyunca süren uygulamalar sonucunda e-portfolyo yönteminin kullanılabilirliği ve uygulama süreci hakkında açık uçlu sorulara verilen cevaplardan elde edilmiştir. Veri analizi için nitel veri araçlarından içerik analizi yöntemi kullanılmıştır. Yapılan çalışma ile öğretmen adaylar e-portfolyonun kullanılabilirliği ve uygulama sürecine yönelik görüşlerini belirtmişlerdir. Öğretmen adaylarının görüşlerden ve ders öğretmeninin gözlemlerinden elde edilen verilerin analizleri doğrultusunda e-portfolyo sisteminin fen bilimleri öğretmeni yetiştirme programına ve öğretmen adaylarının mesleki gelişimlerine katkı sağlayacağı düşünülmektedir.
\end{abstract}

Anahtar kelimeler: E-portfolyo, eylem araştırması, fen bilgisi, kullanışlılık

\section{Review of The Views of Science Teacher Candidates on The Use of E-Portfolio: Action Research}

\begin{abstract}
This research was carried out in order to get the opinions of pre-service science teachers about the usability (positive and negative aspects) of the e-portfolio system, which is used as a performance evaluation method, and the application process. In this context, the experiences of pre-service science teachers as a result of the application study were used. The research, in which the action research method was used, was conducted in a state university in the 2019-2020 academic year. The study group was composed of 17 students studying at the Faculty of Education, Department of Science Education and taking the elective course of Applications of Science in Technology. The research data were obtained from the answers given to open-ended questions about the usability and application process of the e-portfolio method as a result of 10 weeks of applications. Content analysis method, one of the qualitative data tools, was used for data analysis. With the study, the preservice teachers expressed their opinions about the usability and application process of e-portfolio. In line with the analysis of the data obtained from the opinions of the teacher candidates and the observations of the course teacher, it is thought that the e-portfolio system will contribute to the science teacher training program and the professional development of the teacher candidates.
\end{abstract}

Keywords: E-portfolio, action research, science, usefulness 


\section{GİRIS}

Günümüz dünyasında geniş kitlelere hitap eden web uygulamalarının ve çevrimiçi ortamların kullanımı yaygınlaşmakta ve birçok alanda kullanılmaktadır. Bu alanlardan biri olan eğitimde de teknolojinin getirilerinden faydalanılmaktadır. Buna en güzel örneklerden biri ise ülkemizin gelişen teknolojiye uyumunu ve eğitimin niteliğini arttırmayı hedeflemiş olan FATİH (Fırsatları Artırma ve Teknolojiyi İyileştirme Hareketi) projesidir (Milli Eğitim Bakanlığı [MEB], 2019). Bir diğer destekleyici proje ise materyal ve içerik yönünden zengin, öğrenciler ve öğretmenler için destekleyici niteliği olan Eğitimde Bilişim Ağı [EBA] (MEB, 2019) olarak adlandırılan e-platformdur.

Eğitim öğretimde her ne kadar teknolojinin imkânlarından faydalansak da eğitim hedeflerinde ne derecede başarı sağladığımızı görebilmek için değerlendirmeye ihtiyaç duyarız (Kutlu, Polat \& Döşlü, 2014). Değerlendirme aşaması eğitim-öğretimin ayrılmaz bir parçası olarak görülmektedir (Korkmaz \& Kaptan, 2003). Özdemir'in (2010) belirttiği gibi, ölçme ve değerlendirme uygulamalarının amacı öğrencilere not vermek veya bir dersten geçip geçmeme durumunu saptamak değil, aynı zamanda öğrencilerin bireysel farklılıklarını dikkate alarak onların yeteneklerini ortaya çıkarmak; onları ilgi, ihtiyaç ve yeteneklerine uygun biçimde yönlendirmek, bireylerin öğrenme-öğretme süreci boyunca karşılaştıkları zorlukları ve yetersizlikleri belirlemeyip, bunları düzeltmeye çalışmak ve böylece verilen öğretim hizmetinin niteliğini ortaya koymak olmalıdır. Bu bağlamda, ölçme ve değerlendirme nitelikli bir eğitim ve öğretim için de çok önemli bir rol oynamaktadır. Bu bakımdan, eğitim alanında yapılan yenilikler ve değişiklikler değerlendirme yöntemlerini de etkilemektedir. Eğitim süreçlerinde yaygın olarak kullanılan teknoloji, yeni öğretim programlarının amaçları doğrultusunda ölçmedeğerlendirme süreçlerinde de önemli değiş̧iklikler oluşturmuştur (Gömleksiz \& Koç, 2010). Artık değerlendirme, öğrencilerin her bir ünite veya dönem sonunda önceden belirlenen sorulara verdikleri cevapların ölçülmesiyle, onlar hakkında karara varma işlemi olarak görülmemektedir (İzgi \& Gücüm, 2012). Bu şekilde bir sistemi olan geleneksel değerlendirme yaklaşımlarının öğrencilerin öğrenmelerinde sadece not olarak bir değer ifade ettiğini, performans olarak bir değerlendirme yapmadığını söyleyebiliriz. Günümüz eğitim sisteminde, öğrenci merkezli bir eğitim anlayışının popüler olması ile birlikte geleneksel yaklaşımın sonuç odaklı yapısı alternatif değerlendirme ile süreç odaklı bir hal almıştır (Kayri, 2008). Portfolyo değerlendirme de süreç odaklı alternatif değerlendirme yöntemlerinden biridir.

Portfolyo değerlendirme, bireyin öğrenme süreci içerisindeki gelişmesini yine birey tarafından seçilen ürünlerle gösteren ve bireyin kendi öğrenmeleri hakkında öz değerlendirme yapabildiği çok yönlü bir alternatif değerlendirme yöntemidir (Korkmaz \& Kaptan, 2003). Portfolyo değerlendirmenin hem öğrenciye kendi öğrenmesinde, hem de öğretmene öğrenilenlerin gözlenmesinde büyük faydası olduğunu söylenebilir. Nitekim bahsedilen teknolojik gelişim portfolyo sisteminde de değişikliğe neden olmuştur. Ayrıca saklanması, toplanması ve ek kaynaklara ihtiyaç duyulması, öğretmenlerin portfolyo konusunda kaygı yaşamalarına neden olmuştur (Achrazoglou, 2003; Erdemir \& Bakırc1, 2010). Bu bağlamda portfolyoların tasarımı, geliştirilmesi ve değerlendirmesinde bilgisayar teknolojilerinin kullanımı kaçınılmaz olmuş, portfolyo için ara yüz olarak kâğıt sisteminden elektronik sisteme bir geçiş gerçekleşmiştir (Özyenginer, 2006). Bir başka ifadeyle portfolyo, kâğıt üzerinde yazılı dosya biçiminde tutulurken, internet teknolojisinin eğitimde kullanımıyla elektronik ortamlarda oluşturulmaya ve tutulmaya başlanmıştır (Erten, 2015). Portfolyonun bu şekilde değişim göstermesi ile taşıması ve ulaşılması kolay, geleneksel portfolyonun bütün olumlu yönlerine sahip web tabanlı e-portfolyo sistemi oluşmuştur. Geleneksel portfolyodan farklı olarak e-portfolyo da internet üzerinden göndermek, erişmek ve yeniden düzenlemek daha kolaydır (Barış \& Tosun, 2013). 
Ayrıca e-portfolyonun öğrencilerin kendi öğrenmelerinden sorumlu olduğu, kendi gelişimlerini gözleyebildikleri ve öğretmenlerin bireysel gelişimleri sürekli izleyebileceği performans değerlendirme aracı olduğunu söyleyebiliriz. Yaşamdan örnekler sunduğu ve öğrenilenleri dönüt olarak gösterebilmeye olanak tanıdığı için portfolyolar özellikle yetişkinler için fayda sağlamaktadır (Gülbahar \& Köse, 2006). Bu yüzden üniversite düzeyinde ve ürün dosyas1 olarak anlamlı öğrenmenin sağlanabileceği derslerde kullanılmasının oldukça önemli olduğu söylenebilir.

Yapılan araştırmalarda lise öğrencilerinin iletişim teknolojileri dersinde e-portfolyoya yönelik olumlu tutum sergiledikleri görülmüştür (Kutlu vd., 2014). Bir başka araştırma, e-portfolyo sisteminin akademik başarı, tutum, motivasyon üzerindeki etkisi araştırılmış ve deney grubu lehine daha kalıcı öğrenmelerin gerçekleştiği, uygulamaya yönelik tutumların olumlu olduğu sonucu ortaya çıkmış fakat motivasyon olarak anlamlı bir değişiklik gözlenmemiştir (Erten, 2015). Fen eğitiminde yapılan bir e-portfolyo çalışmasında da sınav kaygısı ve öğrenme de kalıcılık üzerine bir çalışma gerçekleştirilmiş ve sonuç olarak kalıcı öğrenme de deney grubu lehine anlamlı bir fark gözlenmiş ama sınav kaygı düzeylerinde istatistiksel olarak anlamlı fark olmadığı tespit edilmiştir (İzgi \& Gücüm, 2012). Öğretmen adaylarının e-portfolyo ile değerlendirmeye yönelik görüşlerinin alındığı bir araştırmada e-portfolyo sisteminin etkileri araştırılmış, sonuç olarak proje tabanlı yöntem ile işlenen derslerde uygun ve faydalı olacağ1 görüşü ortaya çıkmıştır (Gülbahar \& Köse, 2006). Fakat ilgili literatür incelendiğinde, üniversite öğrencilerinin görüşleri yüzeysel bakış açılarıyla ele alınırken, fen bilgisi öğretmen adayları ile ilgili e-portfolyo çalışmalarının da oldukça sınırlı sayıda olduğu görülmektedir.

\section{Araştırmanın Amacı}

$\mathrm{Bu}$ araştırma ile fen bilgisi öğretmen adaylarının e-portfolyo sisteminin kullanılabilirliği ve uygulama süreci ile ilgili görüşlerinin alınması amaçlanmıştır. Araştırmada bilimin teknolojideki uygulamaları seçmeli dersinde, web 2.0 araçları eğitimini gören fen bilgisi öğretmen adaylarının 10 haftalık süre zarfında gördüğü uygulamalarda hazırladığı ürünlerin eporfolyosu oluşturulmuştur. Araştırmanın fen bilgisi öğretmen adaylarını yetiştirme programına ve öğretmen adaylarının mesleki gelişimlerine katkı sağlayacağı düşünülmektedir.

\section{YÖNTEM}

\section{Araştırma Modeli}

Bu çalışmada eylem araştırması türlerinden biri olan ve uygulama odaklı olarak da bilinen teknik/bilimsel/işbirlikçi eylem araştırması ile gerçekleştirilmiştir. Eylem araştırması geliştirilmesi gereken durumla doğrudan ilgili kişilerin araştırmacı olarak çalışmasını gerektiren, geliştirmeye ve iyileştirmeye odaklı bir araştırma türüdür (Büyüköztürk, Çakmak, Akgün, Karadeniz \& Demirel, 2019: 273). Çalışmada fen bilgisi öğretmen adayı yetiştirmede e-portfolyonun kullanılabilirliğini tespit etmek ve nasıl uygulanabileceğini belirlemek için eylem araştırması kullanılmıştır. Çalışma üç aşamada gerçekleştirilmiştir. İlk aşamada problem durumuna yönelik gerekli alanyazın taraması ve meslek deneyiminin sunmuş olduğu gözlemlerden yola çıkarak araştırma problemine karar verilmiştir. İkinci aşama da araştırma problemine yönelik bir eylem planı geliştirilip uygulanmıştır. Üçüncü aşamada ise eylem planı hakkında öğretmen adaylarının görüşleri detaylı bir şekilde analiz edilmişstir. 


\section{Katılimcilar}

Araştırma, bir devlet üniversitesinde, eğitim fakültesinde, fen bilimleri bölümünde 20192020 eğitim-öğretim döneminde öğrenim görmekte olan 3. sınıf 17 fen bilgisi öğretmen adayının katılımıyla gerçekleştirilmiştir. Araştırma olanakların elverişi ve öğrenci sınıf düzeylerinden yapılan gözlemler sonucu amaçlı örnekleme yöntemi ile seçilen bir üniversitenin 3. sınıf fen bilgisi bölümü öğrencilerinin tamamını kapsamaktadır.

\section{Veri Toplama Araçlart}

Fen bilgisi öğretmen adaylarının e-portfolyo kullanımına yönelik görüşlerini belirlemek amacıyla araştırmacı tarafından hazırlanmış ve uzman görüşü ile düzenlenmiş açık uçlu sorular kullanılmıştır. Uzmanlar araştırmacı tarafından belirlenmiş sorulara görüşlerini elektronik ortamda belirtmişlerdir. Öğrencilerin bilimin teknolojideki uygulamaları dersinde e-portfolyo sisteminin kullanılabilirliği ve uygulama süreci ile ilgili fikirlerini alarak uygulanabilirliğini belirlemek adına 8 açık uçlu soru yöneltilmiştir (Tablo 1.).

Tablo 1. E-portfolyo Sisteminin Kullanılabilirliğine ve Uygulanabilirliğine İlişkin Sorular

\begin{tabular}{cl}
\hline Soru & \multicolumn{1}{c}{ Açık uçlu soru } \\
\hline 1 & Sizce e-portfolyo (ürün dosyası) nedir? Açıklayınız. \\
2 & E-portfolyo ile normal portfolyonun farkı nedir? Açıklayınız. \\
3 & E-portfolyo kullanılması öğretmen ve öğrenci açısından ne gibi faydalar sağlar? \\
4 & Kendi e-portfolyonuzu hazırlarken neler yaşadınız? Karşılaştığınız güçlükler nelerdir? \\
5 & Açılayınız. \\
6 & Neden? sonraki eğitim ve meslek hayatınızda e-portfolyo kullanmayı düşünür müsünüz? \\
7 & E-portfolyo fen derslerinde nasıl kullanılabilir? Açıklayınız. \\
8 & E-portfolyo içerisinde neler yer alabilir? E-portfolyoya koyulacak ürünleri seçerken \\
\hline
\end{tabular}

\section{Eylem Planı Geliştirme}

Fen bilgisi öğretmen adayı yetiştirmede kullanılan ölçme-değerlendirme yaklaşımlarında geleneksel yöntem ağır basmakta, çağdaş yöntemlerin kullanımına çok az rastlanılmaktadır. Teknolojinin gelişmesi eğitim camiasında birçok değişikliğe yol açsa da ölçme-değerlendirme çalışmalarında hala geleneksel yöntemler ile değerlendirme çalışmaları devam etmektedir. Bahsedilen bu durumlar için fen öğretmeni yetiştirmede kullanılan klasik ölçme-değerlendirme yöntemlerini değiştirmek ve geliştirmek, çağın gereksinimlerine ayak uyduran gençler yetiştirmek ve mesleki gelişimlerine katkı da bulunmak için bir eylem planı geliştirilip uygulanmıştır.

Öncelikle sınıftaki öğrencilerden gruplar oluşturulmuştur. Grupları 3 veya 4 kişilik olacak şekilde öğrenciler kendileri belirlemişlerdir. Daha eş güdümlü hareket edebilmeleri için kendi seçimlerini gerçekleştirmeleri istenmiştir. Bu grupları oluşturmada temel amaç grup ödevi olarak nitelendirilen bazı ödevlerde iş yükünü hafifletmek, birbirlerini ödevlerden ve durumlarından haberdar etmektir. Ayrıca her grupta internet erişimi olan bir öğrencinin olması hususuna da dikkat edilmiştir. Öğrencilere bazı ödevlerin bireysel bazı ödevlerinde grup olarak 
yapılacağı, bunun ödev talimatı içerisinde belirtileceği ve grup olarak yapılan ödevler bile olsa gruptaki herkesin o ödevi sisteme yüklemesi gerektiği konusunda bilgilendirme yapılmıştır.

Öğrencilere ilk hafta bu ders kapsamında neler işleneceğinden ve e-portfolyo oluşturmak için kullanılacak olan Google Classroom uygulamasından bahsedilmiştir. Google Classroom'a nasıl erişim sağlayacakları, nasıl veri yükleyecekleri ve daha birçok uygulama detayı sınıf ortamında anlatılmıştır. Öğrenciler için gerekli sınıf sistemi öğretmen tarafından oluşturulmuş, öğrenciler öğretmen tarafından verilen sınıf kodu sayesinde kaydını gerçekleştirmiştir. Haftalar içerisinde işlenen konu başlıkları belirtilmiştir (Tablo2).

Tablo 2. Haftalara Ayrılmış Konu Başlıkları

\begin{tabular}{cll}
\hline Haftalar & \multicolumn{1}{c}{ İşlenen Dijital Araçlar } & Uygulamalar \\
\hline 1.Hafta & $\begin{array}{l}\text { Dersin işleniş detayları, Genel } \\
\text { bilgiler }\end{array}$ & Google classroom \\
2. Hafta & Sanal Gerçeklik Araçları & $\begin{array}{l}\text { Dinosaur 4D, Anatomy 4D, Space 4D, } \\
\text { QUiVER, }\end{array}$ \\
& & Algodoo, phet, storyboard that \\
3. Hafta & Hikaye ve Tasarım Araçları & Arduıno, tinkercad, blog kodlama araçları \\
4. Hafta & Robotik Kodlama Araçları & Kahoot, Quiziz, Zipgrade, \\
5. Hafta & Ölçme ve Değerlendirme Araçları & Thatquı, Baamboozle \\
6. Hafta & Ölçme ve Değerlendirme Araçları & Google hangout's, Teamlink, Udemy, Khan \\
7. Hafta & Uzaktan Eğitim Araçları & Academy, TEDx \\
& & Edmodo, Beyazpano, Padlet \\
8. Hafta & Sinıf Yönetim Araçları & Glogster, İnfogram, Pawtoon, Prezi \\
9. Hafta & Sunum ve Poster Hazırlama Araçları & Edpuzzle \\
10. Hafta & Ters Yüz Öğrenme Araçları & Flixpress, Animoto \\
11. Hafta & Video ve Görsel Düzenleme Araçları & .
\end{tabular}

\section{E-Portfolyo Sisteminin Ödevlendirme ve Uygulanma Süreci}

Ödevler Google Classroom uygulamasında; ödevin başlığı, talimatları, son gönderim tarihi gibi detayları ile paylaşılmaktadır. Öğretmenin ve öğrencilerin ödev hakkında yorum yapabilmelerine, gönderdikleri ödev hakkında öğrencinin detaylar sunmasına, öğretmenin geri dönütler vermesine ve beğenmediği ödevi geri teslim edebilmesine kadar birçok imkân ödev içeriğinde sağlanmaktadır. Bahsedilen ifadelerin gerçekleştirildiği görseller aşağıda verilmiştir (Görsel 1 ve Görsel 2). 


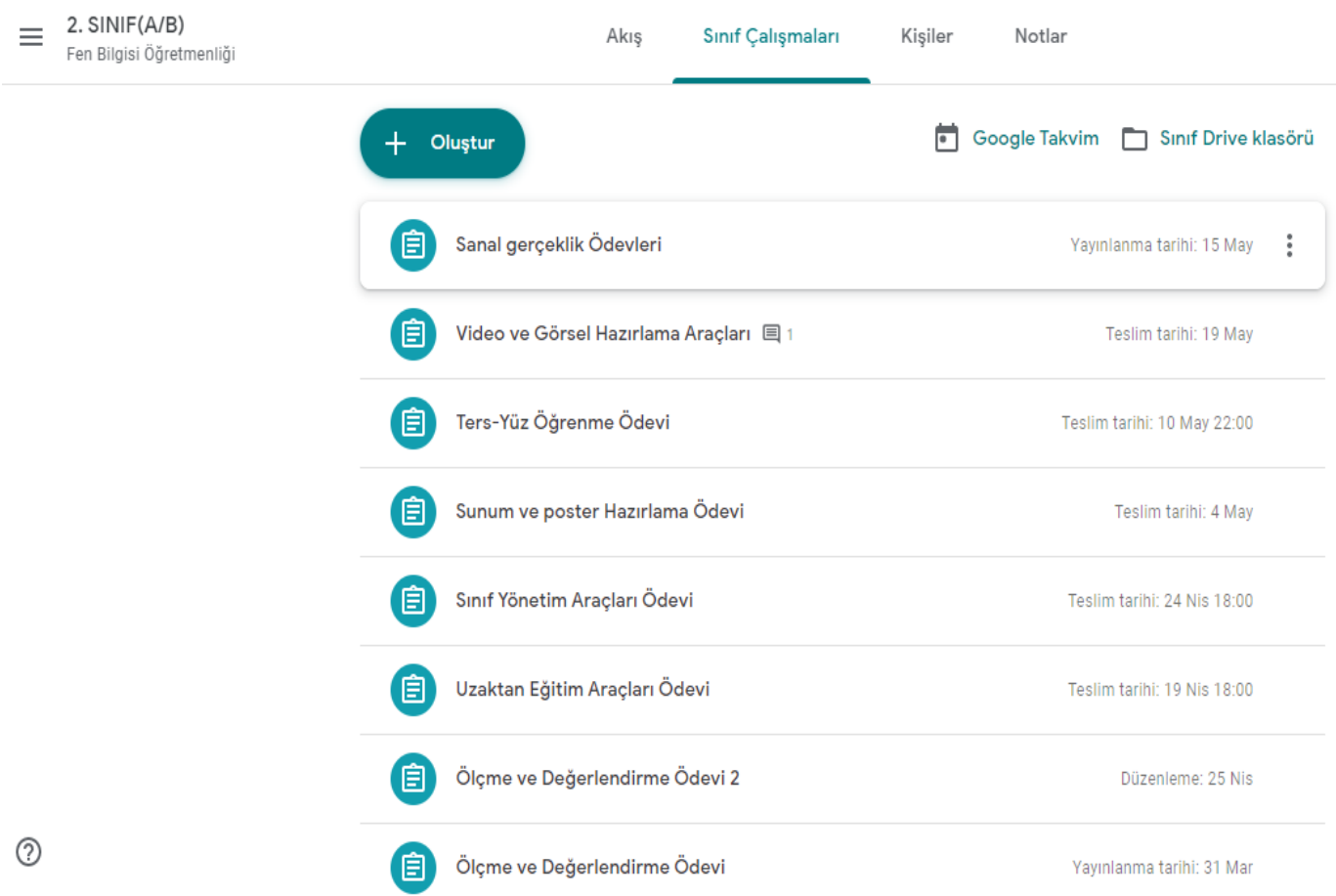

Görsel 1. Ödev Başlıkları

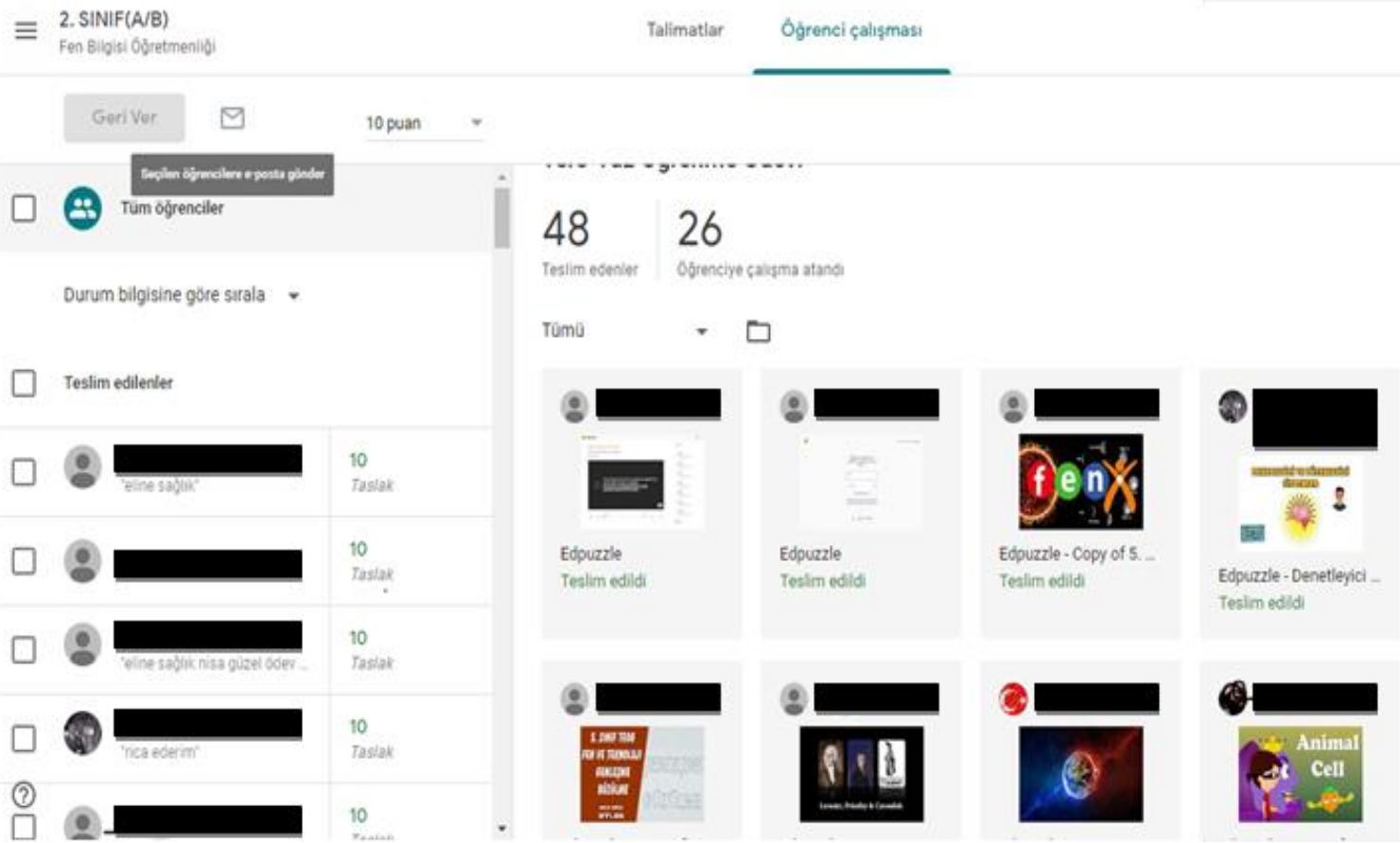

Görsel 2. Ödev Talimatları, Ödevi Görenler ve Teslim Edenler, Öğrenci Ürünleri

\section{E-portfolyo Sisteminin Ödev Değerlendirme Süreci}

Öğrenci ürünleri, ödevlerin niteliğine göre oluşturulmuş olan değerlendirme ölçütleri baz alınarak not verilmiştir (Görsel 3). Öğrencilere kaçlık sistem üzerinden değerlendirme yapılacağı, hangi değerlendirme ölçütünün kullanılacağı öğretmen tarafindan ödev talimatları 
hazırlanırken belirlenmekte ve herkes tarafından görülmektedir (Görsel 4). Ayrıca öğrencilerin ödev başlıkları altında tasarladıkları bütün ödevleri Google drive klasörü içerisinde görülmektedir. Bu sayede öğrenci veya sınıfın oluşturduğu e-portfolyo çalışmalarını istenilen zaman diliminde kolayca elde edebilir (Görsel 5). Ayrıca öğretmenin daha önceden paylaşmış olduğu sunum, resim vb. birçok veriye ulaşılabilmektedir.

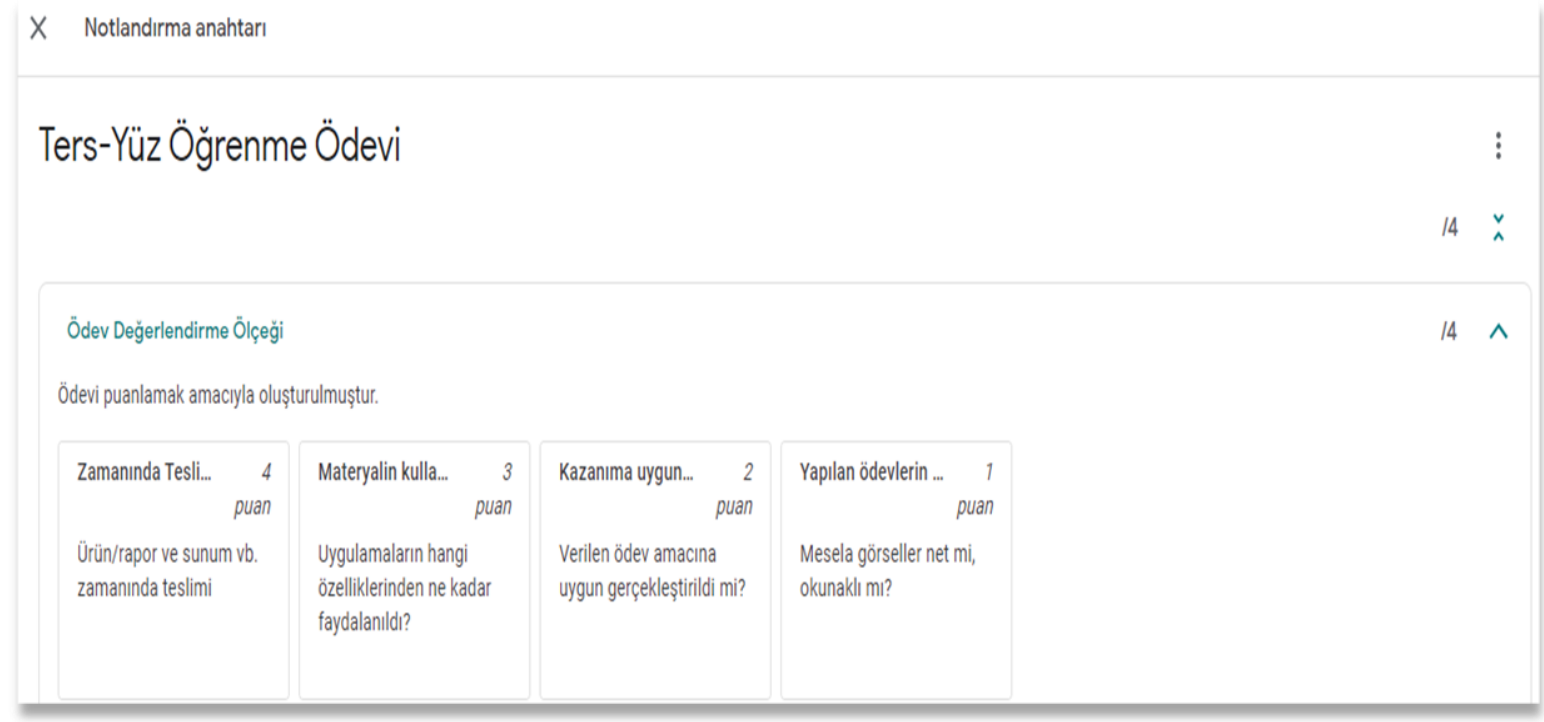

Görsel 3. Ödev Değerlendirme Ölçeği

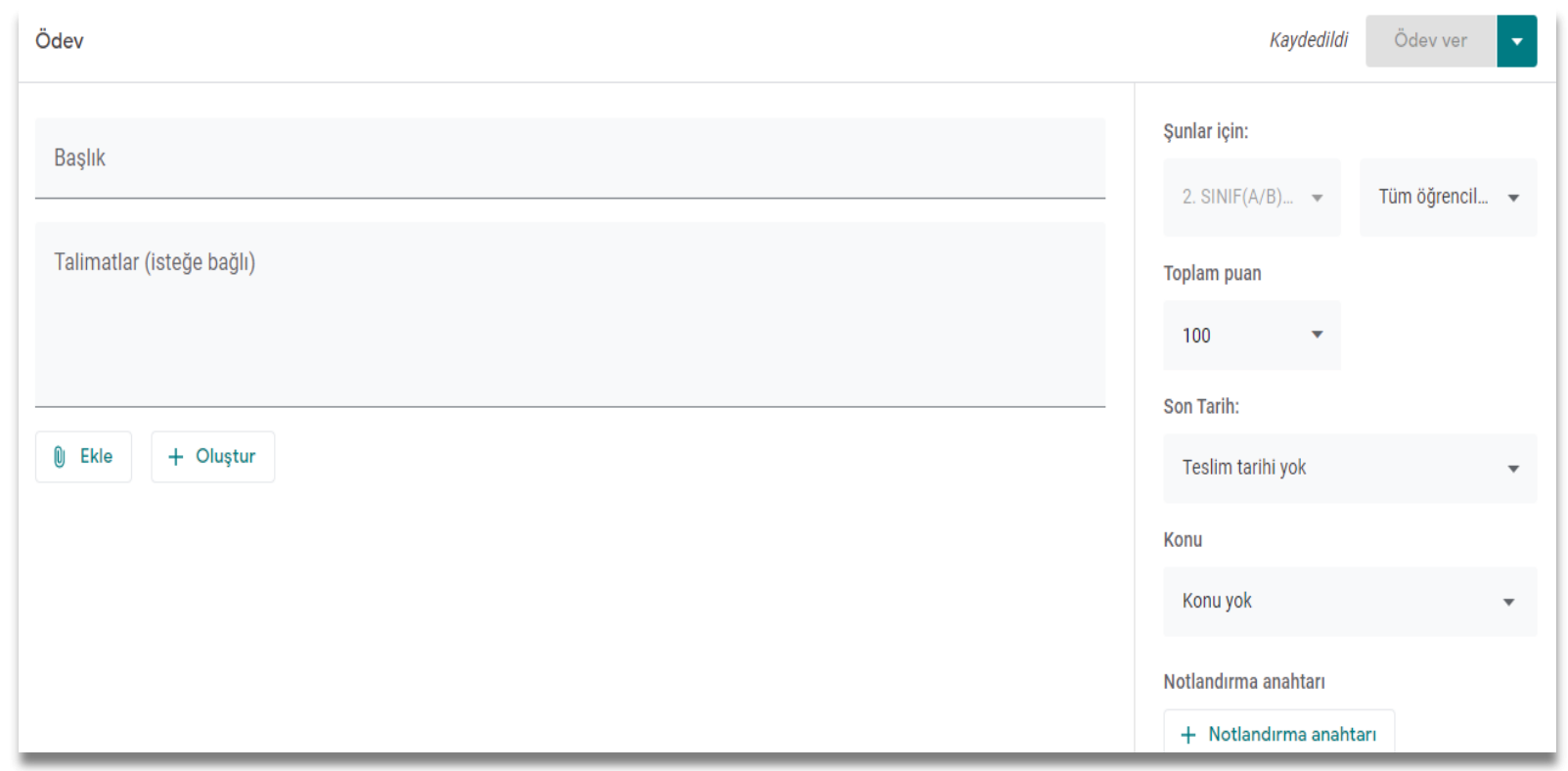

Görsel 4. Ödev Oluşturma Detayları 


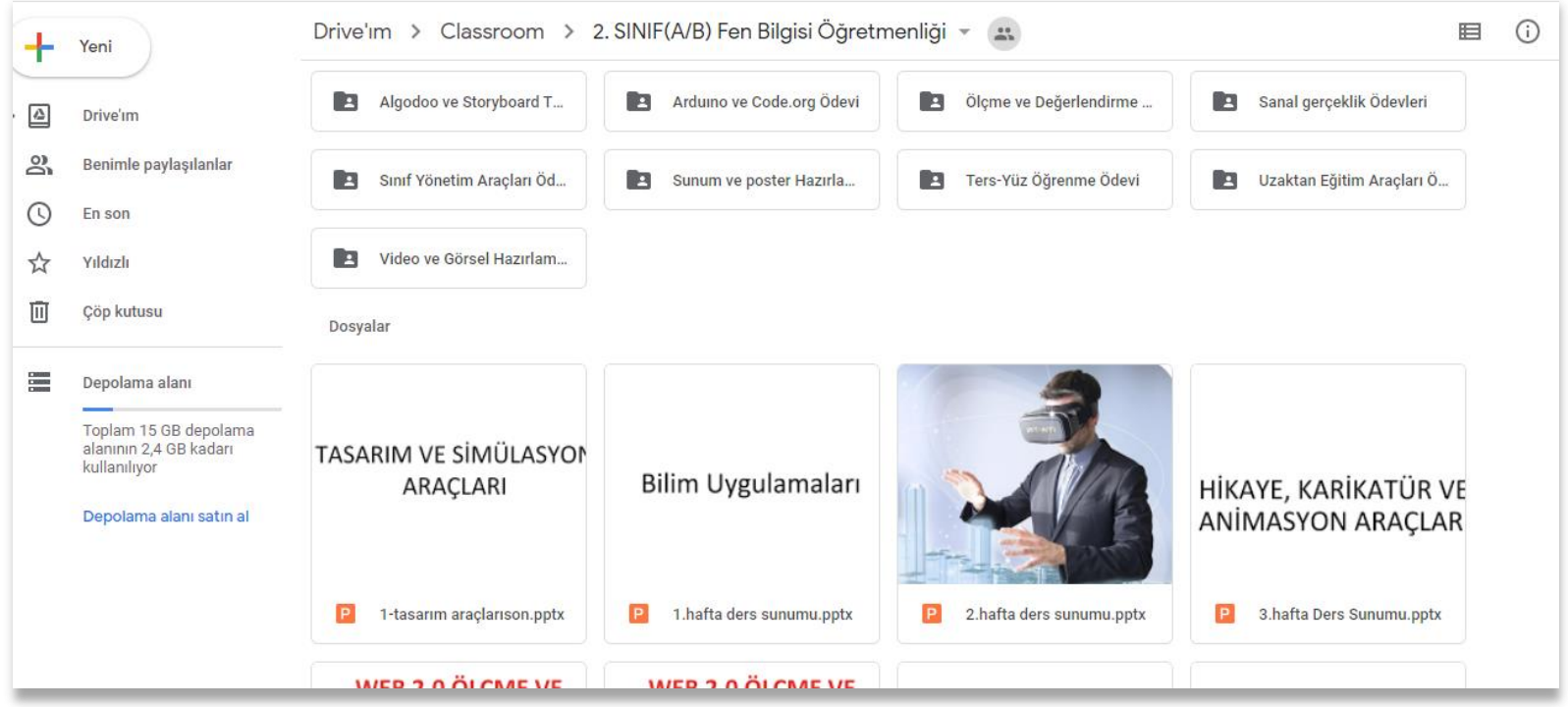

Görsel 5. E-portfolyo İçeriğindeki Tüm Veriler

\section{E-portfolyo Sisteminde Ö̆grenciler ve Notlarının Kayıt Sistemi}

Öğrenciler mail adresi ile giriş yaptıktan sonra sınıf kodu ile sınıfa dahil olmaktadır. Öğrenciler ile kişisel bir iletişime geçmek, ödevlerin bireysel kontrolünü sağlamak ve bu zamana kadar yaptığı çalışmaları gözlemlemek için kişilerim kısmından bütün kayıtlı öğrencilere ulaşılmaktadır (Görsel 6.). Öğrencilerin notlarına erişmek, düzenlemeler yapmak ve not girmek için notlar kısmına tıklayarak erişim gerçekleştirilmektedir (Görsel 7).

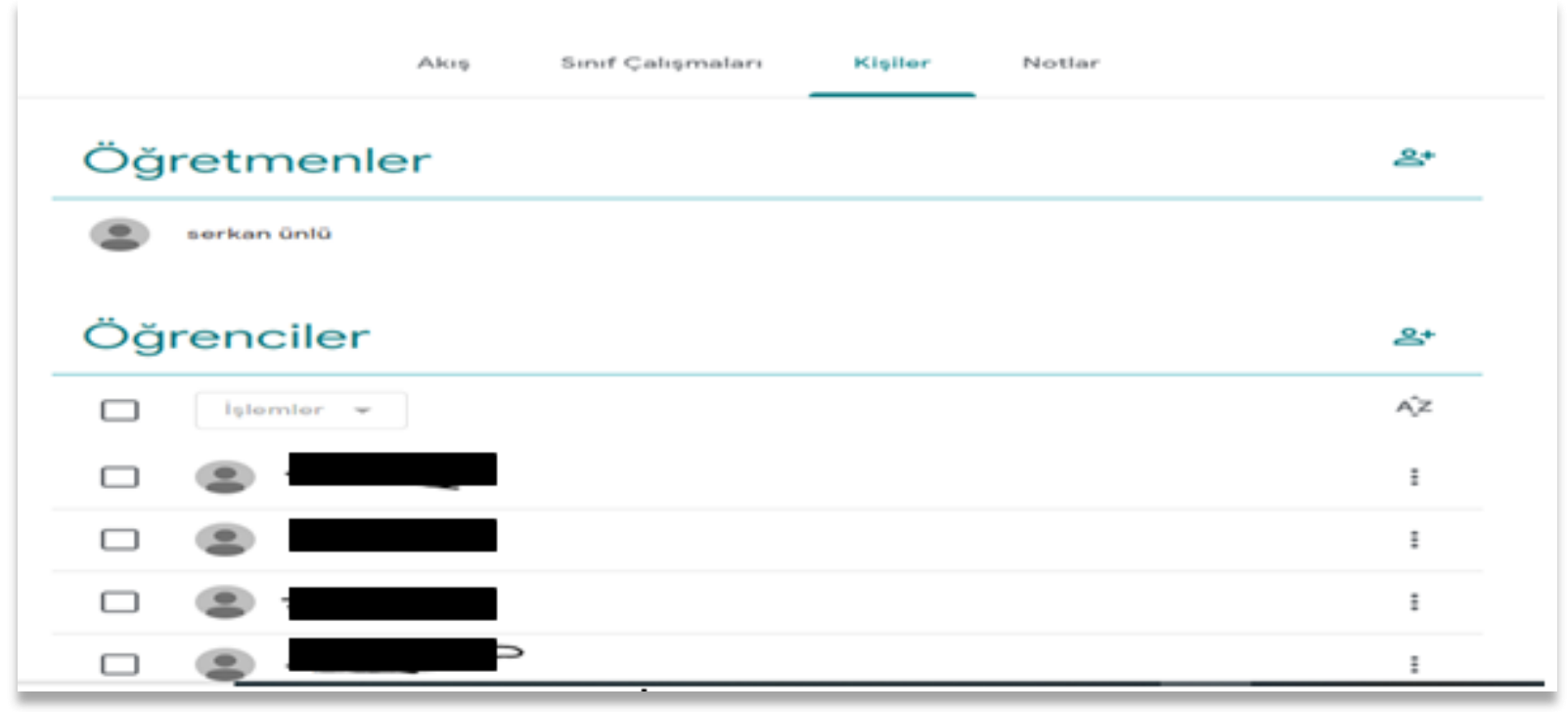

Görsel 6. Kayıtlı Öğrencileri Görüntüleme ve Erişim 


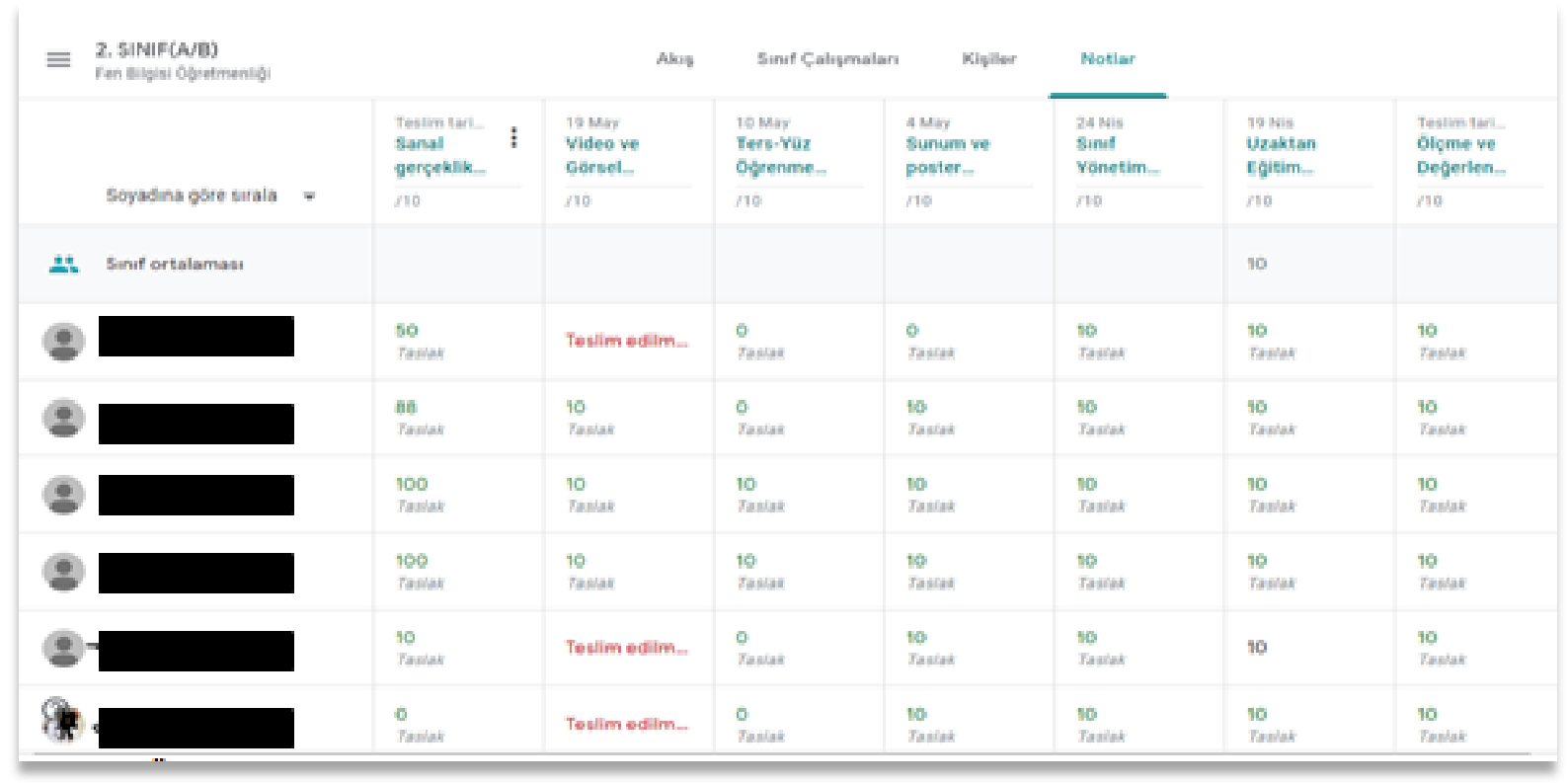

Görsel 7. Öğretmenin Not Sistemine Erişimi

\section{Verilerin Analizi}

Araştırma sürecinde sekiz açık uçlu sorular, araştırmacılar tarafından hazırlanmış ve kapsam geçerliliği için iki alan uzmanının görüşüne sunulmuştur. Uzmanların vermiş oldukları yanıtlardan yararlanılarak soruların anlaşılırlığına yönelik düzeltmeler yapılmış ve son şekli verilmiştir. Açık uçlu sorular ile toplanan veriler içerik analizi tekniği ile değerlendirilmiştir. İçerik analizi, birden fazla kavramdan meydana gelen cümlelerin, belirli bir ilkeye bağlı olarak, içerik öğelerine dönüştürülmesini sağlayan düzenli ve yinelenen bir yöntemdir (Stemler, 2001). Verilerin analizi sürecinde açık uçlu soruların, güvenirliğinin belirlenmesi için Miles ve Huberman'ın (1994) Güvenirlik = Görüş Birliği \[Görüş Birliği + Görüş Ayrılığı]*100 formülü kullanılarak öğrencilerin birbirleri arasındaki uyumluluk oranı hesaplanmıştır. Öğrencilerin birbirleri arasındaki uyumluluk oranı $(0,81)$ olarak hesaplanmış ve yeterli seviyede güvenilir olduğu belirlenmiştir. Analiz sırasında, etik açıdan öğretmen adaylarının isimleri yerine onlara verilen belirli kodlar kullanılmıştır.

\section{BULGULAR}

$\mathrm{Bu}$ araştırmada bulgular, öğretmen adaylarının sorulara verdikleri yanıtların analizinden oluşmaktadır. Öğretmen adaylarının vermiş oldukları yanıtlar tek bir anlayış kategorisi içerisine girmediği durumlarda yanıtların hepsi kodlanmış ve bir öğretmen adayı birden fazla kategoride yer almıştır. $\mathrm{Bu}$ nedenle sayısal değerler öğretmen adaylarının sayısından fazla veya az olmaktadir.

Sizce e-portfolyo (ürün dosyası) nedir? Açıklayınız.. sorusuna öğretmen adaylarının verdikleri yanıtlara göre yapılan içerik analizi sonucunda, öğretmen adayları tarafindan e-portfolyo (ürün dosyas1); \%58 oranında ödevlerin konulduğu dijital dosya, \%11 oranında yeteneklerin sergilendiği, aktif olunan ögrenme kayıt yeri, \%17 oranında etkinliklerin değgerlendirildiğ $i$ sistem, \%11 oranında akademik hayatta yapılan çalışmaları kapsayan dosya olarak algılanmaktadır. Bu aşamada verilen yanıtlar ile ilgili bulgulara Tablo 3' de yer verilmektedir. 
Tablo 3. Tanımlamalara Ait Bulgular

\begin{tabular}{ll}
\hline & Frekans \\
\hline Dijital Dosya Yeri & 10 \\
Değerlendirme Yeri & 3 \\
Öğrenme Kayıt Yeri & 2 \\
Çalışma Dosya Yeri & 2 \\
\hline
\end{tabular}

E-portfolyo ile normal portfolyonun farkı nedir? Açıklayınız.. sorusunun analizinde; \%94 oranında e-portfolyo, internet ortamında yapılan, uzun ömürlü dijital sistem olarak açıklanırken, \%82 oranında normal portfolyo, kağıt üzerine yapılan çalışmalar şeklinde açıklanmıştır. Öğretmen adaylarının \%17'si sadece e-portfolyoyu açıklamış, normal portfolyo ile olan farkı açıklamamıştır. E-portfolyo ile normal portfolyonun farkını ayırt etme ile ilgili bulgular Tablo 4'te verilmektedir.

Tablo 4. Ayırt Edilebilirliğe Ait Bulgular

\begin{tabular}{ll}
\hline & Frekans \\
\hline Farkı Ayırt Etme & 14 \\
Tek Birini Açıklama & 3 \\
\hline
\end{tabular}

Bazı öğrencilerin konuyla ilgili görüşleri şu şekildedir:

"Birisi dijital ortamda kaydedilirken diğerinin ögrencilerin dosya şeklinde saklamalarıdır (Ö1) E-portfolyo daha çok teknoloji becerisi ve bilgisi gerektirir. Normal portfolyo ise de bunlara gerek yoktur (Ö3).Bu çalışmaların farkı biri belge olması diğerinin ise elektronik sertifikaları olmasıdır (Ö8). E-portfolyo internet üzerinden yapılır elimizde doküman yoktur ama portfolyo da bir ürün dosyası vardır ve ögrencinin kağıt üzerine yaptıkları dosyanın içine konulur (Ö12)." şeklinde ifade etmişlerdir.

E-portfolyo kullanılması öğretmen ve öğrenci açısından ne gibi faydalar sağlar? sorusunun analizi sonucunda öğretmenler açısından; \%41 oranında etkileşimi kolaylaştırma, \%58 oranında ögrenciyi takip etme ve \%29 oranında eğitimin kopmadan devam etmesini sağlama ve değerlendirme yapma, şeklinde iken, öğrenci açısından; \%35 oranında etkileşimi kolaylaştırma, $\% 47$ oranında üst düzey becerilerini geliştirme, \%17 oranında eğitimin kopmadan devam etmesini sağlama ve \%41 oranında yaptığ bütün çalışmalara bakma şeklinde ifade edilmiştir. $\mathrm{Bu}$ aşamada öğretmen ve öğrenci açısından fayda oluşturması ile ilgili bulgulara Tablo 5 'te yer verilmektedir.

Tablo 5. Öğretmene ve Öğrenciye Fayda Sağlamasına Ait Bulgular

\begin{tabular}{cc}
\hline & Frekans \\
\hline Öğretmen & 15 \\
Öğrenci & 16 \\
\hline
\end{tabular}


Kendi e-portfolyonuzu hazırlarken neler yaşadınız? Karşılaştı̆̆ınız güçlükler nelerdir? Açılayınız... sorusuna katılımcıların yanıtlarının analizinde; zorlukla karşılaşma oranı \%74 iken, karşılaşmama oranı \%25'i bulmaktadır. Zorlukla karşılaşma nedenlerinde; \%23 oranında elektronik cihaz eksikliği, \%17 oranında ilk defa kullanma, \%17 oranında internetin çekmemesi ve \%17 oranında grup çalışmalarında sorumluluk almayan kişilerin olması görülmektedir. Öğretmen adaylarının \%17'si eğitmenin açıklayıcı anlatımlar yapmasından, \%17'si kolay kullanımının olmasından ve \%11'i sistemin eğlenceli olmasından kaynaklı herhangi bir zorlukla karşılaşmadıklarını ifade etmişlerdir. Ürün dosyasını hazırlarken güçlük yaşama veya yaşamamaya ilişkin bulgulara Tablo 6'da yer verilmektedir.

Tablo 6. Güçlükle Karşılaşmaya Ait Bulgular

\begin{tabular}{ll}
\hline Güçlükle Karşılaşma Durumu & Frekans \\
\hline Evet & 9 \\
Hayır & 8 \\
\hline
\end{tabular}

Bundan sonraki eğitim ve meslek hayatınızda e-portfolyo kullanmayı düşünür müsünüz? Neden? sorusuna öğretmen adaylarının hepsi e-portfolyo sistemini kullanacaklarını ifade etmişlerdir. Nedenlerine bakıldığında ise; \%29'u okul dışında da öğrencileri gözlemleyip, değerlendirmek, \%29'u gelişen teknolojiye ayak uydurmak, \%23'ü kağıt israfi yapılmadan online olarak gerçekleştirmek, \%23'ü düzeneği kolay kurmak, \%29'u iyi bir eğitim vermek ve \%11'i öğrenci ile kolay iletişim sağlamak için e-portfolyo sistemini kullanacaklarını söylemişlerdir.

E-portfolyo fen derslerinde nasıl kullanılabilir? Açıklayınız sorusunun analizi ile simülasyon ve animasyon programlarının hazırlanıp incelenmesi $\% 52$, ihtiyaç halinde geri dönülüp kontrol edilmesi için deneylerin fotoğraflarının çekilmesi $\% 29$, verimliliğin ölçülmesi ve başarının takip edilip, değerlendirilmesi \%23, öğrencileri projelerinin internet üzerinden verilerek, takip edilmesi \%17 oranında çıkmıştır. Hangi yönlerde kullanılabileceğine ilişkin bulgular Tablo 7'de verilmektedir.

Tablo 7. Nerelerde Kullanımının Olacağına Ait Bulgular

\begin{tabular}{ll}
\hline Kullanım Yerleri & Frekans \\
\hline Projeleri Takip Etme & 3 \\
Simülasyon Programlarını Kullanma & 9 \\
Verimlilik Ölçme ve Başarıyı Takip Etme & 4 \\
İhtiyaç Halinde Geri Dönme & 5 \\
\hline
\end{tabular}

Bazı öğrencilerin konuyla ilgili görüşleri şu şekildedir:

"Öğrencilerin yaptı̆̆ projeleri yakından takip edip anında yorum yapabileceğim bir yer olduğu için evde bile devam etse projesine ögrenci, bana atıp orada aşamaların gözlemleyebilirim. Fen dersi çok geniş kapsama yayıld günümüz de ve STEM eğitimi de dâhilinde çocukların teknolojiyi iyice kavramaları için verdiğim ödevleri atmalarında kullanabilirim (Ö4). Örneğin güneşin ve gezegenlerin incelenmesi konusunda sanal gerçeklik araçları kullanılabilir. Animasyonların ve simülasyonların hazırlanıp incelenmesinde, deney malzemeleri elimizde bulunmadı̆̆ zamanlarda bazı uygulamalar üzerinden deneyler izlenebilir (Ö8). Fen dersleri için birçok programlar var similasyon, 
animasyon, kodlama vb. gibi yani bu tür programlardan yardım alarak kullanabiliriz (Ö7)." şeklinde ifade etmişlerdir.

E-portfolyo kullanmanın olumlu ve olumsuz yönleri nelerdir? Açıklayınız sorusunda öğretmen adaylarının verdikleri yanıtların analizinde çoğunluk olarak olumlu yönde açıklamalarının olduğu görülmüştür. Olumlu yönlerine bakıldığında; anında geri dönütlerle konunun pekiştirilmesini sağlayarak anlamlı öğrenmeyi gerçekleştirmesi \%41, yer kavramının olmayış1 ile yapılan çalışmalara kolay ulaşılabilmesi \%41 ve kendini geliştirmesi \%35 oranında çıkmıştır. Olumsuz yönlerine bakıldığında ise; \%47'si internete erişiminin her zaman sağlanamaması, \%11'i yüz yüze değerlendirmenin olmaması şeklinde belirtmişlerdir. $\mathrm{Bu}$ aşamada kullanım ile ilgili olumlu ve olumsuz bulgulara Tablo 8'de yer verilmektedir.

Tablo 8. Görüşlere Ait Bulgular

\begin{tabular}{ll}
\hline Görüşler & Frekans \\
\hline Olumlu Görüş & \\
Anında Geri Dönüt Sağlama & 7 \\
Ulaşımının ve Kullanımın Kolay Olması & 7 \\
Gelişimi Sağlama & 6 \\
Olumsuz Görüş & \\
İnternet Erişiminin Zorluğu & 8 \\
Yüz Yüze Olmaması & 2 \\
\hline
\end{tabular}

Öğrencilerin bazılarının konuyla ilgili görüşleri şu şekildedir:

"E-portfolyoya günümüz teknolojisinde erişemeyen çok az insan var bu ürün dosyasındaki ürünlere erişmek paylaşmak aynı anda birden fazla kişiye ulaştırmak elde edilen ürünü başka bir çalışmada daha rahat kullanmak gibi olumlu yönlere sahip. Olumsuz yönleri ise çok olmamakla birlikte erişme imkânında teknolojik bazı sorunlar olabilir (Ö5). Öğrencinin kendisi için çabalamasını, kendini gösterebilme avantajı çok yüksek öğrencilerin yetenekleri ortaya çıkar ve gelecek için yatırımdır. Teknolojiyi kullanma becerisini gösterir. Teknolojiden ve e portfolyo da ne yapamayacağını bilemez teknolojiye ön yargı ulaşabilir, ihtiyaca cevap vermeyebilir, maliyetli olabilir. Depolamada sıkıntı olabilir ve değerlendirmedi uzun sürebilir (Ö16). Genel olarak kendim de de görmüşs olduğum olumlu etkilerinden klsaca bahsedecek olursam; anlaml bir öğrenme gerçekleştirdiğini söyleyebilirim. Ĕ̆lenceli, geri dönüs yapıp neyin nerde olduğunu bulduğum, birebir aktif katılım ile deneyimlemek teoriğe göre çok daha etkili oldu. Dijitalleşen ortamda da zaten internet üzerindeki programların gelişmesiyle beraber ögrencilerimizin de bu durumlara çok kolay ayak uydurduğunu düşünüyorum. Olumsuz olarak da işte bazı internet kopukluğu veya bilgisayar kaynaklı sebeplerden dolayı kullanım açısından zorlanmıştım (Ö14)." şeklinde ifade etmişlerdir.

E-portfolyo içerisinde neler yer alabilir? E-portfolyoya koyulacak ürünleri seçerken nelere dikkat edilmelidir? Açılayınız sorusuna, öğretmen adaylarından \%58'si özgeçmişlerini, çalışmalarını, ödüllerini e-portfolyo içerisine koyacaklarını söylemişlerdir. Dikkat edilecekler unsurlara ise öğretmen adaylarından \%47'si açık, anlaşı1ır ve düzenli olması, \%29'u ihtiyaçlara göre olması ve \%23'ü içerisindeki bilgilerin doğru olması gerektiğini belirtmişlerdir. İçeriğinin neler olacağına ve dikkat edileceklere ilişkin bulgulara Tablo 9'da yer verilmektedir. 
Tablo 9. İçeriğe Koyulacak ve Dikkat Edilecek Unsurlara Ait Bulgular

\begin{tabular}{lll}
\hline İçeriğe Konulacak Unsurlar & & Frekans \\
\hline İçeriğe Koyulacaklar & Özgeçmişler, Raporlar, Ödüller & 10 \\
Dikkat Edilecekler & Açık, Anlaşılır, Amaca Uygun & 8 \\
& Doğru Bilgi & 4 \\
& İhtiyaca Uygun & 5 \\
\hline
\end{tabular}

Öğretmen gözlemlerine göre fen bilgisi öğretmen adayları e-portfolyo sürecine karşı oldukça olumlu bir bakış açısı kazanmakla birlikte diğer derslerde de ödevlendirmenin bu kadar anlaşı1ır olmasını, öğretmenler ile etkileşimin hızlı ve ulaşılabilir olmasının daha iyi olacağını düşünmektedirler. Ayrıca öğretmen adayları kullandıkları web uygulamalarının isimleri ve nasıl kullanıldığı hakkındaki sorular ile e-portfolyo sürecini mesleki hayatlarında kullanmak adına öğrenmek istemektedirler. E-portfolyonun kullanılabilirliği konusunda öğrencilerin dijital çağa hâkim olmalarından dolayı iletişim ve uygulamalara ulaşımda herhangi bir problem yaşanmamıştır. Bir başka husus ise e-portfolyo sürecinde ödevlerini, projelerini ve tasarımlarını eksiksiz şekilde sisteme yükleyen öğrencilerin hem başarılı olduğunu hem de e-portfolyo kullanımı konusunda daha istekli tavırlar sergiledikleri görülmüştür. E-portfolyo sistemine ürünlerini yüklemelerinde karşılarına çıkan talimatların, son gönderim tarihinin ve not değerinin olması konusunda memnuniyetlerini dile getirirken, ürün yükleme işleminin haftada bir kere olmasından dolayı da memnuniyetsizliklerini dile getirmişlerdir. Öğretmen adaylarına e-portfolyo sürecinde göndermiş oldukları ürünler konusunda birebir dönütler verilmesi de öğretmen adaylarının ortaya koydukları ürünü iyileştirmede ve geliştirmede teşvik etmektedir. Bazı ürünlerin oluşturulmasında grup çalışmasının olması öğretmen adaylarının iş yükünü azalttığı için olumlu görülmektedir. Akran değerlendirmenin olması ve değerlendirmenin dijital ortamda telefon veya bilgisayardan gerçekleştirilmesi süreci daha hızlı ve kolay hale getirmiştir.

\section{TARTIŞMA VE SONUÇ}

Önceden belirtildiği üzere araştırmanın temel amacı fen bilgisi öğretmen adaylarının eportfolyo kullanımına yönelik görüşlerini eylem araştırması yaparak incelemeye çalışmaktır. Burada hem e-portfolyonun eğitim hayatında kullanışlılığını ölçmek hem de eylem araştırmasını öğrenmek hedeflenmiştir. Bu hedeflere ilişkin eylem araştırmasının kuramsal taraması yapılmış ve araştırma problemine karar verilmiştir. Uygulama aşamasında adayların e-portfolyonun kullanılabilirliği hakkındaki görüşleri alınarak analiz edilmeye çalışılmıştır. Uygulama sonuçları bulgular bölümünde açıklanmıştır. Bu bölümde bulgularda çıkan sonuçların yorumlamaları yapıımıştır.

Eylem planına göre düzenlenen ders uygulamasının sonunda alınan yanıtlardan öğretmen adaylarının sınıf içi ve sınıf dışı performanslarının ve derse katılımlarının araştırmanın amacına ulaştığını, dersin aktif ve anlamlı öğrenmeye dayalı bir şekilde teşvik edici olarak işlendiğini ortaya koymuştur. Bu araştırma ile adayların e-portfolyoyu etkin bir şekilde kullanabilmeleri üzerinde çalışılmış ve bu e-portfolyo ile adaylar, öğretmen yetiştirmede kullanılan öğretim programlarına nasıl adapte olabileceklerini gösterme olanağı sağlamışlardır. Verilen görüşlerde adayların e-portfolyo ile ödevlendirme yapılmasının yorucu olduğunu ama ödevi yaparken zevk aldıklarını ve kendilerini geliştirdiklerini belirtmeleri, bu tür uygulamalarının derslerde kullanılması gerekliliğini ortaya çıkarmaktadır. Karşılaşılan yorgunluğa rağmen verilen 
ödevlerin çoğunluğunun doğru ve eksiksiz olarak yapılması, "e-portfolyonun kullanılabilirliği" amacına ulaştığının bir belirtisi olarak gösterilebilir. Ayrıca öğretmen adayları, meslek hayatlarında etkili bir şekilde ders işlemek için e-portfolyoyu kullanmak istediklerini belirtmişlerdir. Bu isteğe bakıldığında içinde bulunduğumuz çağın, teknoloji çağı olmasından ve derslere bütünleştirilmiş olmasının bir sonucu olarak görülebilir.

Güzeller'in (2012) belirttiği gibi teknolojinin eğitim sistemi içerisinde kullanılması, eğitimin gelişmesinde fayda sağlamaktadır. Aynı zamanda teknolojinin eğitime bütünleştirilmesi ile öğrenci motivasyonunu artırdığını ifade eden Uşun'un (2000) sonucundan yola çıkarak öğretmen adaylarının, e-portfolyo kullanımına yönelik düşüncelerinin olmasında etkili olduğu söylenebilir. Eğitimde bilgisayar ve telefon gibi elektronik cihazlara sahip olan, internet aksaklıklarına maruz kalmayan ve uygulamanın nasıl gerçekleşeceğini anlayan adaylar, eportfolyonun kullanılabilirliğine ve süreç içerisinde uygulanabilirliğine dair kavramları daha iyi anlamlandırdıkları sonucu çıkarılabilir. Gömleksiz ve Koç’un (2010) e-portfolyo ile ilgili ortaya koyduğu bir başka boyut ise e-portfolyo sisteminin kullanıcıları araştırmaya teşvik etmesidir. Buradan hareketle e-portfolyonun araştırma ve inceleme becerileri konusunda katk1 sağlayacağına dair olumlu bir bakış açısı oluşturulabilir.

E-portfolyo (ürün dosyası) sistemi öğrencilerin aktif katılımını sağlamak ve iletişim becerilerini arttırmak için kullanılabilir. Hem bireysel hem de işbirliğine dayanan etkinlikler yapma, pekiştirmeler kullanarak anlamlı öğrenmeyi sağlama ve geçmiş çalışmalara bakılarak analizler yapılmasına imkân sağlama açısından önemlidir. Bu nedenle e-portfolyoyu derslerle bütünleştirerek öğrenme-öğretme sürecinin daha eğlenceli ve aktif geçmesine olanak sağlanabilir.

E-portfolyo sistemi başta fen bilimleri öğretmeni yetiştirme programı içerisinde yer alan birçok derste ve öğretmen adayı yetiştirilen birçok bölümde kullanılabilir. Ayrıca teknolojik imkânların her geçen yıl gelişmesi e-portfolyo sistemlerini de etkileyeceği için bu sistemler hakkında mesleklerini icra eden milli eğitim bakanlığı bünyesinde hizmet veren öğretmenlerimize hizmet içi eğitim kapsamında bilgilendirmeler gerçekleştirilebilir. Son zamanlarda e-portfolyo uygulamalarına dâhil edilmeye çalışılan öğrenci velileri hususunda öğrenci gelişimlerinin izlenmesi ve geliştirilmesine yönelik araştırmalar yapılabilir. Ayrıca sistem hakkında velilerin görüşlerini almak adına anketler uygulayarak araştırma derinleştirilebilir.

\section{KAYNAKÇA}

Alan, S. (2014). Illköğretim 4. ve 5. sinıflarda e-portfolyo kullanımının değerlendirilmesi. Yayımlanmamış Doktora Tezi. Necmettin Erbakan Üniversitesi Eğitim Bilimleri Enstitüsü, Konya. https://acikerisim.erbakan.edu.tr/xmlui/handle/20.500.12452/612 adresinden erişilmiştir.

Achrazoglou, G. J. (2003). Assessing teacher preparedness using electronic portfolios and conventional methods. Unpublished Doctoral Dissertation, The University of Iova. Pro Quest Dissertations and Theses (Pro Quest Document ID: 765162681).

Alemdağ, E. (2015). Bilişim teknolojileri öğretmenleri için bir e-mentorluk uygulamasının tasarımı ve etkileri. Yayımlanmamış Yüksek Lisans Tezi. Hacettepe Üniversitesi Eğitim Bil. Ens, Ankara http://www.openaccess.hacettepe.edu.tr:8080/xmlui/bitstream/handle/11655/1753/455501ccbf78-45ab-a580-423d4acc8999.pdf? sequence=1\&isAllowed=y adresinden erişilmiştir.

Barış, M.F. \& Tosun, N. (2013). Influence of e-portfolio supported education process to academic success of the students. Procedia - Social and Behavioral Sciences, 103, 492-499.

Büyüköztürk, Ş., Çakmak, E. K., Akgün, Ö. E., Karadeniz, Ş. \& Demirel, F. (2019). Eğitimde bilimsel araştırma yöntemleri. Ankara: Pegem Yayınc1lık. 
Demirkan, S. (2019). Eğitim yönetiminde alternatif denetim yaklaşımı, öğretmen portfolyosu değerlendirme: bir literatür taraması. Uluslararası Karamanoğlu Mehmetbey Eğitim Araştırmaları Dergisi. 1(1), 49-62.

Erdemir, N. \& Bakırcı, H. (2010). Portfolyonun değişik yerleşim birimlerinde uygulanabilirlik ölçeğinin geçerlik ve güvenirlik çalışması. Elektronik Sosyal Bilimler Dergisi. 9(32), 75-91.

Erten, P. (2015). Çevrimiçi işbirlikli ögrenme ortamında e-portfolyo uygulamasının akademik başarlya, tutumlara, motivasyona ve kalıcılığa etkisi. Yayımlanmamış Doktora Tezi. Fırat Üniversitesi Eğitim Bilimleri Enstitüsü, https://acikerisim.firat.edu.tr/xmlui/bitstream/handle/11508/12254/423420.pdf?sequence=1\&is Allowed $=y$ a adresinden erişilmiştir.

Gömleksiz, M. N. \& Koç, A. (2010). Bilgisayar okuryazarllğ 1 becerisi ediniminde e-portfolyo sürecinin öğrenen performansına ve tutumlarına etkisi. Erzincan Eğitim Fakültesi Dergisi. 12(2).75-96.

Gülbahar, Y. \& Köse, F. (2006). Öğretmen adaylarının değerlendirme için elektronik portfolyo kullanımına ilişkin görüşleri. Ankara Üniversitesi Eğitim Fakültesi Dergisi. 39(2), 75-93.

Gürol, M. \& Demirli, C. (2006). E-portfolyo sürecinde ögrenci motivasyonu. 6th International Educational Technology

Conference. https://www.researchgate.net/profile/Nuran_Kemankasli2/publication/322209861_Geometri_O gretiminde_Etkinlikler_Ip_Yardimiyla_Dinamik_Sekiller/links/5a4bb72c0f7e9b8284c2dc12/G eometri-Oegretiminde-Etkinlikler-Ip-Yardimiyla-Dinamik-Sekiller.pdf\#page=792 adresinden erişilmiş̧ir.

Güzeller, C.O. (2012). Web tabanlı portföy kullanımının akademik başarı ve elde tutma üzerindeki etkisi. Asya Pasifik Educ. Rev. 13, 457-464.

İzgi, Ü. \& Gücüm, B. (2012). Fen eğitiminde portfolyo değerlendirme kullanımının sınav kaygısı ve öğrenmenin kalıcılığı üzerine etkisi. Eğitim ve Bilim Dergisi (Education and Science ), 37(164), 71-80.

Kaptan, F. \& Korkmaz, H. (2003). İlköğretim fen öğretmenlerinin portfolyoların uygulanabilirliğine yönelik güçlükler hakkındaki algıları. Pamukkale Üniversitesi Eğitim Fakültesi Dergisi, 1(13), 159-166.

Kayri, M. (2008). Elektronik portfolyo değerlendirmeleri için veri madenciliği yaklaşımı. Yüzüncü Y11 Üniversitesi, Eğitim Fakültesi Dergisi, 5(1), 98-110.

Kutlu, M. O., Polat, Y. \& Döşlü, A. (2014). Ortaöğretim 10.sınıf bilgi ve iletişim teknolojileri dersinde web tabanlı portfolyo kullanımı-Adana ilinde bir çalışma. Çukurova Üniversitesi Sosyal Bilimler Enstitüsü Dergisi, 23(1), 336-351.

Miles, M. B., \& Huberman, A. M. (1994). Qualitative data analysis: An expanded sourcebook (3rd ed.). Sage Publications.

Milli Eğitim Bakanlığı (2019). Fen bilimleri ögretim programı (İlkokul ve ortaokul 3,4,5,6,7 ve 8. siniflar). Ankara: MEB Yayınevi.

Morkoç, D. K. \& Erdönmez, C. (2015). Web 2.0 uygulamalarının eğitim süreçlerine etkisi: Çanakkale sosyal bilimler meslek yüksekokulu örneği. Yükseköğretim ve Bilim Dergisi, 5(3), 335-346. DOI: $10.5961 /$ jhes.2015.135

Özdemir, S.M. (2010). İlköğretim öğretmenlerinin alternatif ölçme ve değerlendirme araçlarına ilişkin yeterlikleri ve hizmet içi eğitim ihtiyaçları. Türk Eğitim Bilimleri Dergisi, 8(4), 787-816.

Özyenginer, E. (2006). Bilgisayar dersinde elektronik portfolyo yöntemi kullanımı üzerine bir çalışma. Yayımlanmamış Yüksek Lisans Tezi. Dokuz Eylül Üniversitesi Eğitim Bilimleri Enstitüsü. İzmir. http://acikerisim.deu.edu.tr:8080/xmlui/bitstream/handle/20.500.12397/7457/189825.pdf?seque $\underline{\text { nce }=1}$ adresinden erişilmiştir. 
Polat, M. \& Köse Y. (2013). Okullarda bir performans değerlendirme aracı olarak e-portfolyo kullanımına yönelik ilköğretim öğretmenlerinin görüşleri. Bilgisayar ve Eğitim Araşstırmaları Dergisi, 1(1), 59-82.

Stemler, S. (2001). An overview of content analysis. Practical Assessment, Research \& Evaluation, 7(17). https://scholarworks.umass.edu/pare/vol7/iss 1/17/ adresinden erişilmiştir.

Uşun, S. (2000). Dünyada ve Türkiye'de bilgisayar destekli öğretim. Ankara: Pegem A Yayıncılık

Yuladır, C. \& Doğan, S. (2009). Fen ve Teknoloji dersinde öğrencilerin ev ödevi performansını arttırmaya yönelik bir eylem araştırmas1. Journal of Arts and Sciences, 12, 211-236.

\section{Kaynak gösterimi için (for cite in):}

Ülker, F.T., Ünlü, S. \& Usta, E. (2021). Fen bilgisi öğretmen adaylarının e-portfolyo kullanımına yönelik görüşlerinin incelenmesi: bir eylem araştırması. Turkish Journal of Primary Education (TUJPED), 6 (1), 1-17. doi: 10.52797/tujped.747510

\section{EXTENDED ABSTRACT}

\section{Introduction}

Today, developments in technology affect the education field as well as many other fields. With the advances in technology, online environments. The use of information and communication technologies has also increased due to the widespread use of advanced websites and wide network connections. Information and The developments in communication technologies are very important in terms of educational activities with the ease of accessing and disseminating information. Smart boards, tablets, mobile applications, interactive and educational software used in the field of education demonstrate this importance. These opportunities in education Although it is benefited, the use of the same opportunities is very rare in controlling what is learned. The traditional paper system, which is an important part of education and in the evaluation phase where learning is supervised, continues its dominance. We can say that alternative approaches, which have differentiated this situation, are very important for evaluation.

Portfolio applications, which is one of the alternative methods, is one of the methods that can be used as an evaluation tool in today's student-centered education approach. This method, which can be described as a student product file, is a method in which products and processes obtained from students can be observed. As a result, the e-portfolio system is a digital and interactive version of the normal portfolio. In this way, it is very important for teachers to know and apply the digital activities. Teacher candidates should be trained to create and set up eportfolio systems to meet the needs of the age. The aim of this research is to get the opinions of prospective teachers about the usability and practice process of the e-portfolio system within the framework of an action plan. This research was carried out by the action research method. This research is expected to contribute to the science teacher training program and the professional development of teachers.

\section{Method}

This study was carried out at a public university in the 2019-2020 academic year using the action research method. Content analysis method, one of the qualitative data tools, was used to collect data. Content analysis is a regular and recurring method that allows sentences consisting of multiple concepts to be converted into content elements, depending on a specific principle. 
Open-ended questions were used to determine pre-service teachers' views on e-portfolio use. The research data were obtained from the answers given to open-ended questions about the usability of the e-portfolio method and the application process as a result of the practices lasting for 10 weeks. It was made by coding method according to the categories extracted from the data. The data were analyzed by descriptive statistics. Expert opinion has been applied to ensure reliability.

\section{Findings}

As a result of the research, various findings emerged and these findings were discussed and interpreted. In cases where the responses given by the teacher candidates did not fall within a single category of understanding, the responses were all coded and one teacher candidate was included in more than one category. Therefore, numerical values are more or less than the number of teacher candidates. According to the teacher observations, science teacher candidates gain a positive perspective towards the e-portfolio process. Interaction with teachers is fast and accessible. Since the students have mastered the digital age in terms of the availability of eportfolio, there has been no problem in accessing communication and applications. students who submitted their homework complete and accurate were found to be more successful. Group work has been received positively because it reduces the workload of teacher candidates. Giving one-to-one feedback on the products they sent to the teacher candidates during the eportfolio process provides active participation in the lesson.

\section{Discussion and Conclusion}

According to the results of the research, some recommendations can be made for practitioners and researchers. With this research, it has been studied that candidates can use the e-portfolio effectively, and with this e-portfolio, candidates have the opportunity to demonstrate how they can adapt to the teaching programs used in teacher training. Teacher candidates have stated that they want to use the e-portfolio to effectively process lessons in their professional lives. When you look at this request, it can be seen as that the age we are in is technology age and integrated into the lessons. Its use within the education system benefits the development of education (Güzeller, 2012). The e-portfolio system can be used in many courses and departments. The research can be deepened by applying surveys to get parents' opinions about e-portfolio. In line with these recommendations, different perspectives can be brought to the subject and a contribution can be made to the literature. 